\title{
Examining the Impact of Novel Pre-activity Tasks on Macro-Skills: The Case of Visual Aids Strategy on Writing Ability
}

\author{
Hooshang Khoshsima, Mahboobeh Khosravani" \\ English Language Department, Chabahar Maritime University, Chabahar, Iran \\ Email address: \\ Khoshsima2002@yahoo.com (H. Khoshsima),Khosravani7@gmail.com (M. Khosravani)
}

\section{To cite this article:}

Hooshang Khoshsima, Mahboobeh Khosravani. Examining the Impact of Novel Pre-activity Tasks on Macro-Skills: The Case of Visual Aids Strategy on Writing Ability. International Journal of Language and Linguistics. Vol. 3, No. 6, 2015, pp. 401-408. doi: $10.11648 / \mathrm{j} . \mathrm{ij} 11.20150306 .23$

\begin{abstract}
The main concern of most researchers in the field of second and foreign language teaching is lessening the problems and eliminating the hinders on the way of learning a language. Writing is considered as one of the most challenging and complicated tasks for learners to perform particularly when they have to write in a second or foreign language. In fact, writing is difficult for students as it demands other linguistic, cognitive and metacognitive strategies to be used (Rao, 2007). Numerous studies were done on the importance of the pre-writing stage and activities which are directly and indirectly related to the theme of the writing. Go (1994) states that teachers of English as a Second Language can use prewriting activities at the earliest stages of instruction to help their students acquire good language skills. The main aim of this study was to examine the effects of visual aids as a pre- activity task on writing ability. To this aim 25 Iranian EFL learners, who are at the same level-intermediate- studying at Shokuh and Safir Institutes, Birjand, Iran were chosen. Two groups- one control and one experimental group- were studied. In control group the conventional method was used, while in experimental group, visual aids pre-activity task was administered. Both groups met the same level -Intermediate. At the end, the obtained data of the tests was analyzed by SPSS software. According to the obtained data researcher strongly concluded that visual aids had strongly a positive effect on the learners' writing ability. This study can help teachers and syllabus designers in choosing and applying an effective pre-activity task.
\end{abstract}

Keywords: Writing Ability, Pre-Task, Visual Aids, EFL Learners

\section{Introduction}

Writing is considered as one of the most challenging and complicated tasks for learners to perform particularly when they have to write in a second or foreign language. All of us may experience it when we start to write about something, we face a lot of difficulties especially in the very beginning. In another words, writing is not only to put our pen on paper and place the words in their right place. In fact, writing is difficult for students as it demands other linguistic, cognitive and metacognitive strategies to be used (Rao, 2007). Furthermore, Pishghadam and Ghanizadeh (2006) proposed that although students pass several years in writing classes, still they have a lot of problems in the process of writing.

On the other hand, the importance and necessity of writing skill is clear for all teachers and researchers as it enables them to think critically, organize their opinions, and finally to compose what they have in their mind. Rao (2007) indicated the importance of writing in this way,

Writing has always been regarded as an important skill in the teaching and learning English as a Foreign Language (EFL). On the one hand, it stimulates thinking, compels students to concentrate and organize their ideas, and cultivates their ability to summarize, analyze, and criticize. On the other hand, it reinforces learning in, thinking in, and reflecting on the English language (p.100).

It is believed that most students have difficulty in the very beginning of writing (Mousapour negari, 2011). All the time, students express their complaints that they cannot organize their thoughts and write about something engrossing and relevant to the topic. Although teachers are aware of these problems, they cannot find suitable techniques to eliminate students' obstacles in the processes of writing (Rao, 2007). Before starting to write, as Pishghadam and Ghanizadeh (2006) suggested, students need more preparations and exercises to 
overcome the difficulties of writing. As a result, teachers should pay more attention on prewriting stage. Recently, a large number of studies are done to examine the effects of prewriting tasks on writing ability. The term 'pre-writing' has two different meanings. It can mean the stage before children learn writing, which is referred to as hand skills. The other meaning, which is the concern of this study, relates to a pre-activity like using visual aids strategy.

In the process of teaching, all the time teachers are trying to draw students' attention more. One of the strategies that teachers can use is using visuals. Visuals are the materials that can be seen like pictures, poster, graphics, videos, charts, flash cards etc. (Asokhia, 2009, p. 81).

In second language learning, using visual aids is a necessity teaching strategy in both English as Second Language (ESL) classroom and English as Foreign Language (EFL) classroom (Allen, Kate \& Marquez, 2011).

\section{Review of Literature}

\subsection{Writing Skill}

According to Chastain (1988) "Writing is a basic communication skill and a unique asset in the process of learning a second language. Producing a successful written text is a task which requires simultaneous control over a number of language systems." (p. 244) Many scholars believe that teaching writing should be in a way that stimulates student output and only then should generate teacher response and conferencing (e.g Reid, 1993).

According to Widdowson (1983), writing is an interactive process of negotiation. However, providing a coherent and cohesive piece of writing is difficult since, as Zamel (1987) states, writing has a complex, recursive and non-linear nature requiring a variety of micro-skills. This might be a reason why there is no agreement among second language scholars over the best approach to teach or learn it.

A considerable body of literature on L2 writing (e.g. East, 2008; Zamel, 1987) challenges the product approach and, instead, focuses on the process-oriented view. Based on Zamel (1983), researchers have found that the investigation of students' written products do not demonstrate much about their instructional needs. That is why they are now exploring writing behaviors, which can offer insight into how to teach it. In this view, what is required is the implementation of a supportive environment in which L2 learners are encouraged to take risk and get engaged in creating meaning.

In addition, the negotiation on assessment practice is indicative of the conflict between two main approaches towards writing. According to East (2008), "one view is influenced by knowledge-based approaches that favor the static assessment of writing. The advocates of this view use tests that produce a snapshot of the L2 test takers' writing ability and measure knowledge of key components. They emphasize the discriminatory power of the test to predict future success. The other view is affected by the process-oriented approach that focuses on dynamic assessment, which is more learner-centered. Based on this view, the proficiency construct of communicative writing is as an authentic reflection of writing as process.” (p. 37)

\subsection{Pre-writing Activities}

Starting writing is a problem for many, especially young writers. Tompkins (2001) points out that the most neglected stage is the pre-writing stage. Blackburn-Brockman (2001) signalizes that many pre-service teacher education students in a composition methods course confess they did not prewrite seriously in middle and high school, and that many did not pre-write at all. However, it is an important phase in the writing process frequently overlooked by beginning writers. Thorne (1993) indicates that prewriting is the most important skill to emphasize and practice extensively in basic writing classes. She describes basic writers as almost universally neglecting prewriting activities. She suggests some guidelines for teaching prewriting effectively.

The term 'pre-writing' has two different meanings. It can mean the stage before children learn writing, which is referred to as hand skills. The other meaning, which is the concern of this study, relates to pre-activities like pre-questioning, using visual aids, and group discussion.

As the researcher believes, the schema theory which was explained in details in the pre-writing part of this chapter is also directly related to pre-writing activities as well. This claim is mentioned because the ultimate goal of using pre-writing activities is activating or developing students' background knowledge to write more successfully. Therefore, the researcher refers you to the information presented in the pre-reading part of this chapter and does not replicate those aforementioned ideas on schema theory, background knowledge and so on.

\subsection{Visual Aids}

In second language learning, using visual aids is a necessity teaching strategy in both English as Second Language (ESL) classroom and English as Foreign Language (EFL) classroom (Allen, Kate \& Marquez, 2011). They believed that using visual aids in the process of teaching a foreign language can strengthen what learners have learned and increase their interest. In their article, they proposed the positive impact of using visuals and they concluded that teachers should become aware of the strategies in which they can use visual aids and use them purposefully in the classroom to enhance students' learning.

Visual aids can be defined as using objects, drawings, charts, photographs, videos, multimedia presentation, etc. in the classroom. During our everyday life, all the time we are in contact with lots of visuals, which can be beneficial for learning too. Researchers believed in the positive effect of visuals on learning.

Yunus, Salehi, and John (2013) conducted a research to investigate the teachers' opinion toward using visual aids in classroom. Therefore, they selected 52 English teachers in Malaysia and interviewed with them. The majority of teachers believed in the significant effect of visual aids on teaching materials. In fact, they used visual aids to engage the students 
and also make the materials more interesting for them.

Craig and Amernic (2006) tried to investigate the effect of using PowerPoint as a visual aid on learning. They believed that in all educational settings there should be appropriate and complete presentation to enhance the learning of students. So using PowerPoint as a valuable educational tool will enable them to accomplish this goal.

As all these studies indicate, visual aids can provide us with a new way of enhancing learning. Visual aid is a broad concept and includes different types, so as whole researchers and teachers believe in using visual aids. The primary purpose of visual aids users is to engage students more and to help them to learn new materials better.

\section{Research Question and Hypothesis}

RQ. Does visual aids strategy as a pre- activity task have a significant effect on writing ability of Iranian intermediate EFL learners?

H0. Visual aids strategy as a pre- activity task has no significant effect on writing ability of Iranian intermediate EFL learners

\section{Method}

\subsection{Participants}

The participants of this study are 25 Iranian EFL learners, who are at the same level -intermediate- studying at Shokuh and Safir Institutes, Birjand, Iran. Their age range is among 16 to 25. Both male and female students were entered to this study. These participants were in two classes- 13 participants in the control group, and 12 participants in visual aids group. The specifications of these 25 participants are given in table 1 .

Table 1. participants'Specifications.

\begin{tabular}{llll}
\hline & & Number & Percent \\
\hline \multirow{2}{*}{ Gender } & Male & 15 & $60 \%$ \\
& Female & 10 & $40 \%$ \\
\multirow{2}{*}{ Age } & $16-20$ & 8 & $32 \%$ \\
& $20-25$ & 17 & $68 \%$ \\
\hline
\end{tabular}

\subsection{Instruments and Material}

In this part all instruments and materials which were used for conducting this research will be mentioned. The materials and instruments which used for carrying on this study are as follow.

\subsubsection{TOEFL Tests}

TOEFL test (Test of English as a Foreign Language) is one of the most acceptable and well-known tests all over world. Nowadays, most researchers use TOEFL tests to obtain their required data as there is no doubt about their validity and reliability. TOEFL tests are in two formats: PBT (Paper-based Test) and iBT (Internet-based Test). Although iBT innovated in late 2005, it could replace progressively PBT and CBT (Computer-based Test). By the way, PBT is still in use in some regions. TOEFL test integrates all four skills -reading, writing, speaking, and listening- to measure the overall skill of communicating in foreign language. In details, in a TOEFL test, the testee is subject to a reading test and has to read a text and answer a number of questions, a writing test and has to write properly about a certain topic, a listening test and has to listen to conversations and answer questions, and finally a speaking test and has to speak about a certain topic.

In this study, the researcher preferred to use a Paper-Based version of TOEFL taken from Longman Preparation Course for the TOEFL Test (the Paper Based Test) (Phillips, 2005). As only intermediate students are involve in this study, at first, the researcher administered a TOEFL proficiency test to all participants to ensure that all of them met the intermediate level. Then, one TOEFL writing ability test was used at the outset of the study as the pre-test in both groups. This pre-test was also used to check the homogeneity of the participants and to ensure that their writing ability was also at the same level. Additionally, one TOEFL writing test was administered in these two groups at the end of treatment as the post-test. The readability scale was used to make sure that the tests are at the same level.

\subsubsection{SPSS (Statistical Package for the Social Science) Software}

SPSS software is worldwide software which is used for statistical analysis to a great degree. All essential statistical analysis of this study was done by use of $20^{\text {th }}$ version of SPSS software. The data collected from TOEFL tests were analyzed by SPSS software.

\section{Procedure}

In this study, two groups- one control and one experimental group- were studied. In control group the conventional method was used, while in experimental group, visual aids pre-activity task was administered. Both groups met the same level -Intermediate. In each session, writing was taught based on this specific pre- activity task. In the first session, before performing any treatment, one pre-test of writing was administered in each group. Then, the treatments were conducted in 16 sessions. The levels of all tests were checked by readability scale which revealed that all tests were at the same level of difficulty. A TOEFL proficiency test was used to check the homogeneity of the participants. After that, the process of teaching was started and this pre- activity task was applied in the experimental group. In the last session, a writing ability test was administered in each of those two groups. The writing tests were corrected by two teachers. At the end, the obtained data of the tests was analyzed by SPSS software which are revealed in the next part.

\section{Results}

This part is particularized to analyze the effect of visual aids as a pre-activity on writing ability. The research question of this study which is "Does visual aids strategy as a pre- activity task have a significant effect on writing ability of Iranian 
intermediate EFL learners?" will be answered in this part. To meet this aim, independent sample t-tests are used. The first one is specialized for pretests to prove the homogeneity of groups, and the second one to compare posttest to reject or support hypothesis.

Table 2. Group Statistics.

\begin{tabular}{|c|c|c|c|c|c|}
\hline & Pretest & $\mathbf{N}$ & Mean & Std. Deviation & Std. Error Mean \\
\hline \multirow{2}{*}{ pretest writing scores } & pretest visual aids group & 12 & 6.0833 & 2.13290 & .61571 \\
\hline & pretest control group & 13 & 6.5577 & 1.40740 & .39034 \\
\hline
\end{tabular}

Table 2 illustrates distinctly that as mean score and standard deviation for visual aids group are 6.08 and 2.1 and for control group are 6.5 and 1.4, so these groups were very similar at the outset of the study. Otherwise stated, visual aids group and control group are homogeneous.

Next table also illustrated the same reality in other words.

Table 3. Independent Samples Test.

\begin{tabular}{|c|c|c|c|c|c|c|c|c|c|c|}
\hline & & \multicolumn{2}{|c|}{$\begin{array}{l}\text { Levene's Test for } \\
\text { Equality of Variances }\end{array}$} & \multicolumn{7}{|c|}{ t-test for Equality of Means } \\
\hline & & \multirow[t]{2}{*}{$\mathbf{F}$} & \multirow[t]{2}{*}{ Sig. } & \multirow[t]{2}{*}{$\mathbf{t}$} & \multirow[t]{2}{*}{ df } & \multirow[t]{2}{*}{ Sig. (2-tailed) } & \multirow{2}{*}{$\begin{array}{l}\text { Mean } \\
\text { Difference }\end{array}$} & \multirow{2}{*}{$\begin{array}{l}\text { Std. Error } \\
\text { Difference }\end{array}$} & \multicolumn{2}{|c|}{$\begin{array}{l}95 \% \text { Confidence Interval of } \\
\text { the Difference }\end{array}$} \\
\hline & & & & & & & & & Lower & Upper \\
\hline \multirow{2}{*}{$\begin{array}{l}\text { Pretest } \\
\text { writing } \\
\text { scores }\end{array}$} & $\begin{array}{l}\text { Equal variances } \\
\text { assumed }\end{array}$ & 1.524 & .230 & -.661 & 23 & .515 & -.47436 & .71714 & -1.95788 & 1.00916 \\
\hline & $\begin{array}{l}\text { Equal variances not } \\
\text { assumed }\end{array}$ & & & -.651 & 18.831 & .523 & -.47436 & .72902 & -2.00114 & 1.05243 \\
\hline
\end{tabular}

Table 3 represented the value that $\mathrm{t}=-.66, \mathrm{df}=23$, and $\mathrm{p}=.51$. In fact as significant value is more than .05 , there is no significant difference between visual aids group and control group. These two groups were homogenous at the scratch.

Table 4. Group Statistics.

\begin{tabular}{llllll}
\hline & Posttest & N & Mean & Std. Deviation & Std. Error Mean \\
\hline \multirow{2}{*}{ posttest writing scores } & Posttest visual aids group & 12 & 7.9583 & 1.03810 & .29967 \\
& posttest control group & 13 & 6.6731 & 1.44476 & .40071 \\
\hline
\end{tabular}

Table 4 is designed to compare the posttests of these groups to verify whether these groups are different significantly or not. As the mean scores are visual aids group and control group are 7.9 and 6.6 respectively, it proves that visual aids group improved but not significantly. In other words, visual aids group didn't outperform control group.

Table 5. Independent Samples Test.

\begin{tabular}{|c|c|c|c|c|c|c|c|c|c|c|}
\hline & & \multicolumn{2}{|c|}{$\begin{array}{l}\text { Levene's Test for } \\
\text { Equality of Variances }\end{array}$} & \multicolumn{7}{|c|}{ t-test for Equality of Means } \\
\hline & & \multirow[t]{2}{*}{$\mathbf{F}$} & \multirow[t]{2}{*}{ Sig. } & \multirow[t]{2}{*}{$\mathbf{t}$} & \multirow[t]{2}{*}{ df } & \multirow{2}{*}{$\begin{array}{l}\text { Sig. } \\
\text { (2-tailed) }\end{array}$} & \multirow{2}{*}{$\begin{array}{l}\text { Mean } \\
\text { Difference }\end{array}$} & \multirow{2}{*}{$\begin{array}{l}\text { Std. Error } \\
\text { Difference }\end{array}$} & \multicolumn{2}{|c|}{$\begin{array}{l}95 \% \text { Confidence Interval } \\
\text { of the Difference }\end{array}$} \\
\hline & & & & & & & & & Lower & Upper \\
\hline \multirow{2}{*}{$\begin{array}{l}\text { Posttest } \\
\text { writing } \\
\text { scores }\end{array}$} & $\begin{array}{l}\text { Equal variances } \\
\text { assumed }\end{array}$ & 1.421 & .245 & 2.535 & 23 & .019 & 1.28526 & .50707 & .23630 & 2.33422 \\
\hline & $\begin{array}{l}\text { Equal variances not } \\
\text { assumed }\end{array}$ & & & 2.569 & 21.754 & .018 & 1.28526 & .50037 & .24687 & 2.32364 \\
\hline
\end{tabular}

According to the obtained data which are displayed in table $5, \mathrm{t}=2.5, \mathrm{df}=23$, and significant value is .019 which is less than.05. As a result, using visual aids as a pre-activity has a significant effect on writing ability of subjects. In other words, experimental group which enjoys visual aids as a pre-activity outperforms control group. The fifth null hypothesis which is "Visual aids as a pre-activity task has no significant effect on writing ability of Iranian intermediate EFL learners" is rejected.

\section{Discussion}

It is proved that the pre- activity task -visual aids- has a significant effect on writing ability. Researcher tried to gear up some pictures related to the topic and talk about each of them. So students can use the presented information in their writing. Pictures were successful to draw students' attention and increase their motivation. As proposed by Allen et al (2011) that using visual aids in the process of teaching will increase students' interest and strengthen their learning. They also believed that teachers should try to find out some strategies which enable them to use this pre-activity. In conclusion, as Hill (1990) stated, using visual aids has some advantages like being availability, flexibility, and always fresh and different. 


\section{Conclusion}

As discussed in this study, the main concern of most researchers in the field of second and foreign language teaching is lessening the problems and eliminating the hinders on the way of learning a language. Consequently, many researchers have found out that using pre-activities in the process of teaching second/foreign languages is helpful. Therefore, the main aim of this study was to examine the effects of visual aids strategy as a pre- activity task on writing ability. As the data illustrated, visual aids had strongly a positive effect on the learners' writing ability. The participants using this pre- activity could outperform the control group. Therefore, it can be surely suggested to educators to employ this pre- activity task in their teachings.

\section{Appendices}

\section{Appendix A (Writing Tests)}

\section{Writing Test 1}

Some people have the dream of traveling to Niagara Falls, while others don't care. What about you? Do you like to see Niagara Falls or not? Support your idea with reasons and examples (In about three paragraphs).

\section{Writing Test 2}

Some people have the dream of traveling to moon, while others don't care. What about you? Support your idea with reasons and examples (In about 3 paragraphs).

\section{Writing Test 3}

Some people believe that bees are dangerous creatures, while others consider them as useful creatures. Do you agree with the first one or the second one? Use specific reasons and examples to support your reasons (In about 3 paragraphs).

\section{Writing Test 4}

What do you know about the origin of the expression "once a blue moon"? Write specifically about the meaning of this expression and its origin (In 3 paragraphs).

\section{Appendix B (TOEFL Proficiency Test: Sample Pages)}

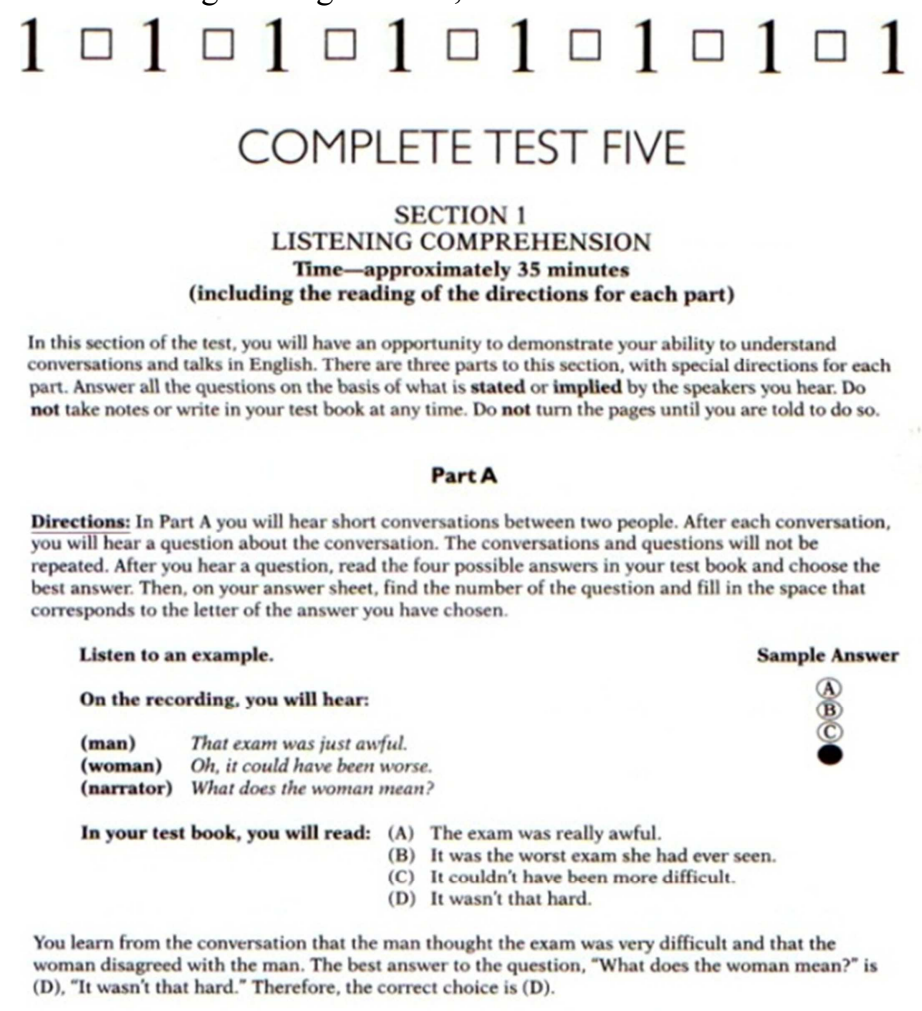

Fig. 1. TOEFL proficiency test, the first page of section one as a sample. 


\section{$2 \cdot 2 \cdot 2 \cdot 2 \cdot 2 \cdot 2 \cdot 2 \cdot 2$ \\ SECTION 2 \\ STRUCTURE AND WRITTEN EXPRESSION \\ Time-25 minutes \\ (including the reading of the directions) \\ Now set your clock for 25 minutes.}

This section is designed to measure your ability to recognize language that is appropriate for standard written English. There are two types of questions in this section, with special directions for each type.

\section{Structure}

Directions: These questions are incomplete sentences. Beneath each sentence you will see four words or phrases, marked (A), (B), (C), and (D). Choose the one word or phrase that best completes the sentence. Then, on your answer sheet, find the number of the question and fill in the space that corresponds to the letter of the answer you have chosen.

Look at the following examples.

\section{Example I}

The president the election by a landslide.
(A) won
(B) he won
(C) yesterday
(D) fortunately

The sentence should read, "The president won the election by a landslide." Therefore, you should choose answer (A).

\section{Example II}

\section{Sample Answer}

When _the conference?
(A) the doctor attended
(B) did the doctor attend
(C) the doctor will attend
(D) the doctor's attendance

The sentence should read, "When did the doctor attend the conference?" Therefore, you should choose answer (B).

Fig. 2. TOEFL proficiency test, the first page of section two as a sample. 


\title{
$3 \triangle 3 \triangle 3 \triangle 3 \triangle 3 \triangle 3 \triangle 3 \triangle 3$
}

\author{
SECTION 3 \\ READING COMPREHENSION \\ Time-55 minutes \\ (including the reading of the directions) \\ Now set your clock for 55 minutes.
}

This section is designed to measure your ability to read and understand short passages similar in topic and style to those that students are likely to encounter in North American universities and colleges. This section contains reading passages and questions about the passages.

Directions: In this section you will read several passages. Each one is followed by a number of questions about it. You are to choose the one best answer, (A), (B), (C), or (D), to each question. Then, on your answer sheet, find the number of the question and fill in the space that corresponds to the letter of the answer you have chosen.

Answer all questions about the information in a passage on the basis of what is stated or implied in that passage.

Read the following passage:

John Quincy Adams, who served as the sixth president of the United States from 1825 to 1829 , is today recognized for his masterful statesmanship and diplomacy. He dedicated his life to public service, both in the presidency and in the various other political offices that he Line held. Throughout his political career he demonstrated his unswerving belief in freedom of

(5) speech, the antislavery cause, and the right of Americans to be free from European and Asian domination.

\section{Example I}

Sample Answer

To what did John Quincy Adams devote his life?
(A) Improving his personal life
(B) Serving the public
(C) Increasing his fortune
(D) Working on his private business

According to the passage, John Quincy Adams "dedicated his life to public service." Therefore, you should choose answer (B).

\section{Example II}

In line 4, the word "unswerving" is closest in meaning to
(A) moveable
(B) insignificant
(C) unchanging
(D) diplomatic

The passage states that John Quincy Adams demonstrated his unswerving belief "throughout his career." This implies that the belief did not change. Therefore, you should choose answer (C). 


\section{References}

[1] K. Allen and A. Marquez, "Teaching vocabulary with visual aids," Journal of Kao Ying Industrial \& Commercial Vocational High School , pp. 1-5, 2011.

[2] R. J. Craig and J. H. Amernic , "PowerPoint presentation technology and the dynamics of teaching," Innov High Educ, 31, 147-160. doi: 10.1007/s10755-006-9017-5

[3] M. O. Asokhia, "Improvisation/teaching aids: aid to effective teaching of English language," Int. J. Edu. Sci, pp. 79-85, 2009.

[4] E. Blackburn-Brockman, "Prewriting, Planning, and Professional Communication," English J, pp. 51-53, 2001.

[5] K. Chastain, Developing second language skills: Theory and practice (3rd ed.), Chicago: HBJ, 1988.

[6] M. East, "Dictionary use in foreign language writing exams: Impact and implications," International Journal of Lexicography, pp. 344-348, 2008.

[7] G. Mousapour Negari, "A Study on Strategy Instruction and EFL Learners' Writing Skill," International Journal of English Linguistics,pp. 299-307, 2011. doi:10.5539/ijel.v1n2p299
[8] R. Pishghadam and A. Ghanizadeh, "On the Impact of Concept Mapping as a Prewriting Activity on EFL Learners' Writing Ability," IJAL Journal, 2006.

[9] Z. Rao, "Training in Brainstorming and Developing Writing Skills," ELT Journal, pp. 100-106, 2007.

[10] J. Reid, Teaching ESL Writing. Englewood Cliffs, NJ: Regents Prentice Hall, 1993.

[11] S. Thorne, "Prewriting: A basic skill for basic writers," Teaching English in the Two-Year College, pp. 31-36, 1993.

[12] G. E. Tompkins, Literacy for the 21st century: A balanced approach. Columbus, OH: Merrill Prentice Hall, 2001.

[13] H. Widdowson, Learning purpose and language use. Oxford: Oxford University Press, 1983.

[14] M. M. Yunus, H. Salehi, and S. A. John, "Using visual aids as a motivational tool in enhancing students' interest in reading literary text," Recent Advances in Educational Technologies, p. 114, 2013.

[15] V. Zamel, "Recent research on writing pedagogy," TESOL Quarterly, pp. 697-715, 1987.

[16] V. Zamel, "The composing processes of advanced ESL students: Six cases studies," TESOL Quarterly, pp. 165-187, 1983. 